\title{
Gliding mutants of Mycoplasma mobile: relationships between motility and cell morphology, cell adhesion and microcolony formation
}

\author{
Makoto Miyata, ${ }^{1}$ Hitoshi Yamamoto, ${ }^{1}$ Takashi Shimizu, ${ }^{1} \dagger$ \\ Atsuko Uenoyama, ${ }^{1}$ Christine $\mathrm{Citti}^{2}$ and Renate Rosengarten ${ }^{2}$
}

Author for correspondence: Makoto Miyata. Tel: +8166605 3157. Fax: +81666053158. e-mail:miyata@sci.osaka-cu.ac.jp

1 Department of Biology, Graduate School of Science, Osaka City University, Sumiyoshi-ku, Osaka 558-8585, Japan

2 Institute of Bacteriology, Mycology and Hygiene, University of Veterinary Medicine, Veterinärplatz 1, A-1210 Vienna, Austria

\begin{abstract}
The present study characterizes gliding motility mutants of Mycoplasma mobile which were obtained by UV irradiation. They were identified by their abnormal colony shapes in $0.1 \%$ agar medium, showing a reduced number of satellite colonies compared to the wild-type. A total of ten mutants were isolated based on their colony phenotype. Using dark-field and electron microscopy, two classes of mutants, group I and group II, were defined. Cells of group I mutants had irregular, flexible and sometimes elongated head-like structures and showed a tendency to aggregate. Neither binding to glass nor gliding motility was observed in these mutants. Cells of group II mutants were rather spherical in shape, with the long axis reduced to $80 \%$ and the short axis enlarged to $120 \%$ of that of wild-type cells, respectively. Their gliding speed was $20 \%$ faster than that of wild-type cells. Three of the ten mutants remained unclassified. Mutant $\mathrm{m} 6$ had a reduced binding activity to glass and a reduced gliding motility with $50 \%$ of the speed of the wild-type strain. The ability of wild-type and mutant colonies to adsorb erythrocytes was found to correlate with the binding activity required for gliding, indicating that mycoplasma gliding depends on cytadherence-associated components. Finally, the ability to form microcolonies on surfaces was shown to correlate with the gliding activity, suggesting a certain role of gliding motility in the parasitic life-cycle of mycoplasmas.
\end{abstract}

Keywords: mollicutes, Mycoplasma mobile, gliding mutants, cell morphology, cell adhesion

\section{INTRODUCTION}

Mycoplasmas are wall-less parasitic prokaryotes, phylogenetically related to low G + C Gram-positive bacteria (Weisburg et al., 1989), and are widespread in man, animals and plants (Razin, 1995). Gliding motility, a movement by which cells attach to various matrices and slide on them, has been reported for several mycoplasma species, including Mycoplasma pneumoniae, Mycoplasma pulmonis, Mycoplasma gallisepticum, Mycoplasma genitalium and Mycoplasma mobile (Kirchhoff, 1992; Razin, 1995). Gliding motility has been reported for a variety of bacteria, for example Myxococcus

†Present address: Department of Bacteriology, Kurume University, School of Medicine, Asahimachi 67, Kurume 830-0011, Japan. and Flavobacterium species, as well as cyanobacteria (Burchard, 1981; Wall \& Kaiser, 1999). Interestingly, the twitching motility and pathogenic determinants of Pseudomonas aeruginosa and Neisseria gonorrhoeae share essential genes with the gliding motility of Myxococcus (Youderian, 1998). In these Gram-negative bacteria, several factors are known to be involved in gliding, including type IV pili, surface proteins, chemotactic signal pathway components, lipopolysaccharides and extracellular polysaccharides. The gliding mechanisms are still unclear, although several hypotheses have been suggested based on the information available (Hoiczyk \& Baumeister, 1998; Manson et al., 1998).

The genomes of two gliding mycoplasmas, $M$. genitalium and M. pneumoniae, have been fully sequenced (Fraser et al., 1995; Himmelreich et al., 1996). 
However, the genome sequence does not have homologues for components of pili, chemotactic signal pathways or two-component systems of bacteria. This suggests that mycoplasmas have a distinct gliding mechanism which requires experimental analysis (Himmelreich et al., 1996).

M. mobile was isolated from the gill organ of a freshwater fish (Kirchhoff \& Rosengarten, 1984). Previous work has shown that $M$. mobile has great advantages for analysis of gliding motility for the following reasons (Kirchhoff, 1992): (i) it glides with a speed of $2 \cdot 0-4 \cdot 5 \mu \mathrm{m} \mathrm{s}^{-1}$, five times faster than the second fastest mycoplasma, M. pulmonis; (ii) the movement is continuous and is not interrupted by resting periods, as reported for other mycoplasmas; (iii) the optimal temperature for gliding is $25^{\circ} \mathrm{C}$, which allows microscopic observation at normal room temperature (Rosengarten \& Kirchhoff, 1987).

Mycoplasmas are classified phylogenetically into five groups based on $16 \mathrm{~S}$ rRNA structures. M. mobile belongs to the Mycoplasma hominis group, which also includes M. pulmonis, whilst the fully sequenced mycoplasmas, M. pneumoniae and M. genitalium, belong to the M. pneumoniae group (Weisburg et al., 1989). Nevertheless, the apparent cell structures involved in gliding motility are common among the gliding mycoplasmas and the gliding mechanism is believed to be similar in these species (Kirchhoff, 1992; Miyata \& Seto, 1999).

One possible approach to elucidate the gliding mechanism is the isolation of gliding mutants, but so far, no such mutant has been reported for mycoplasmas. To investigate the mechanism of gliding, gliding mutants of M. mobile were identified and isolated, and characterized with regard to their motility, cell morphology, adhesive capability and potential for microcolony formation.

\section{METHODS}

Cultivation. M. mobile strain 163K (ATCC 43663) was grown without shaking at $25^{\circ} \mathrm{C}$ in Aluotto medium, consisting of $2.1 \%$ heart infusion broth, $0.56 \%$ yeast extract and $10 \%$ serum (Aluotto et al., 1970), supplemented with $25 \mu \mathrm{g}$ thallium acetate $\mathrm{ml}^{-1}$ and $50 \mu \mathrm{g}$ ampicillin $\mathrm{ml}^{-1}$.

Isolation of gliding mutants. Exponential-phase cells were collected by centrifugation at $15000 \mathrm{~g}$ and $20^{\circ} \mathrm{C}$ for $10 \mathrm{~min}$ and suspended in a buffer consisting of $8 \mathrm{mM}$ HEPES ( $\mathrm{pH} 7 \cdot 4$ ) and $280 \mathrm{mM}$ sucrose. Cell suspension $(500 \mu \mathrm{l})$ was aliquoted to a depth of $2.5 \mathrm{~mm}$ into a 24 -well tissue culture plate and irradiated at $25^{\circ} \mathrm{C}$ for 10 min by UV light generated by a $4 \mathrm{~W}$ lamp placed at a distance of $10 \mathrm{~cm}$ and equipped with a filter that allowed light with wavelengths above $254 \mathrm{~nm}$ to pass through. The irradiated cells were collected by centrifugation at $15000 \mathrm{~g}$ and $20^{\circ} \mathrm{C}$ for $5 \mathrm{~min}$ and suspended in liquid medium to a concentration of about 1000 c.f.u. $\mathrm{ml}^{-1}$. Aliquots $(20 \mu \mathrm{l})$ of the cell suspension were used to inoculate Aluotto medium containing $0 \cdot 1 \%$ Noble agar (Difco) in 24-well tissue culture plates. After $4-5 \mathrm{~d}$ incubation at $25{ }^{\circ} \mathrm{C}$ in a moist chamber, mutants were identified based on their colony morphology. The cell shape and motility of the isolated mutants were examined by dark-field microscopy after $1 \mathrm{~d}$ growth in broth medium. The cells were suspended by pipetting several times, the absence of clumps confirmed by microscopy and the suspension inoculated again onto $0 \cdot 1 \%$ agar medium. After some days of cultivation, colony morphology and features of cell morphology were examined. This screening procedure was repeated a few times until each mutant showed uniform colony morphology and cell morphological characteristics, i.e. did not differ from the characteristics observed in the previous screening procedure.

Microscopic observation and analysis of movements. To examine gliding motility for screening purposes, $3 \mu \mathrm{l}$ of broth culture or a colony that had been suspended in broth medium was placed on a glass slide and covered with a coverslip. For quantitative analysis, cells were harvested by centrifugation at $10000 \mathrm{~g}$ and $20^{\circ} \mathrm{C}$ for $4 \mathrm{~min}$ and suspended in fresh broth medium to reach a cell concentration allowing easy observation of cell motility, namely $10-1000$ cells in a microscope field. Cell movements were examined under a microscope (BX50; Olympus) equipped with a dark-field condenser lens (U-DCW) and were recorded with a video camera recorder through a CCD (charge-coupled device) camera (WV-BP510; Panasonic). Video files were produced from the videotapes using a personal computer through an image capture card (Qmotion, Quadrant International) and converted to sets of frames. The frame sets were analysed with the software Scion Image PC (Scion). Average images were produced and used as still images. The moving tracks were traced by a painting tool with a fixed width, and the lengths of traces were measured using particle analysis software. A total of 50 tracks of $2 \mathrm{~s}$ and 10 tracks of $10 \mathrm{~s}$ were traced to estimate the gliding speeds of M. mobile mutants $\mathrm{m} 6$ and $\mathrm{m} 26$, respectively. More than 100 tracks of $4 \mathrm{~s}$ were used for other movements. For analysis of cell shape by dark-field microscopy, image files of single frames were produced from the videotapes. Cell shape characteristics were obtained from 100 cell images with Scion Image PC. For electron microscopic observation, cells were placed on collodion-coated grids prepared as described by Fareed \& Kasamatsu (1980). Grids were allowed to dry, negatively stained with $2 \%$ ammonium molybdate for $1.5 \mathrm{~min}$ and observed with a transmission electron microscope (Cole, 1983; Seto \& Miyata, 1998, 1999).

Haemadsorption assay. Colonies grown on $0.7 \%$ agar medium for $5 \mathrm{~d}$ were overlaid with sheep erythrocytes suspended in PBS as described by Sobeslavsky et al., 1968) and observed under an inverted microscope. After washing with PBS, the number of attached erythrocytes and the colony area were measured with Scion Image PC, and the ratio was used to quantify haemadsorption activity.

Microcolony formation. M. mobile cells were inoculated into $200 \mu \mathrm{l}$ Aluotto broth medium in wells of 96-well microtitre plates to a concentration of $1 \times 10^{7}$ c.f.u. $\mathrm{ml}^{-1}$. The microtitre plates were incubated at $25^{\circ} \mathrm{C}$ on the stage of an inverted microscope and observed continuously for $72 \mathrm{~h}$ with the CCD camera connected to a time-lapse video recorder. Alternatively, mycoplasmas were grown in an incubator at $25^{\circ} \mathrm{C}$ and the microcolonies were observed and photographed after $60 \mathrm{~h}$.

\section{RESULTS}

\section{Colony shapes in low agar concentrations}

Previous reports have shown that swarming motility and gliding are more prominent when cells are grown on 

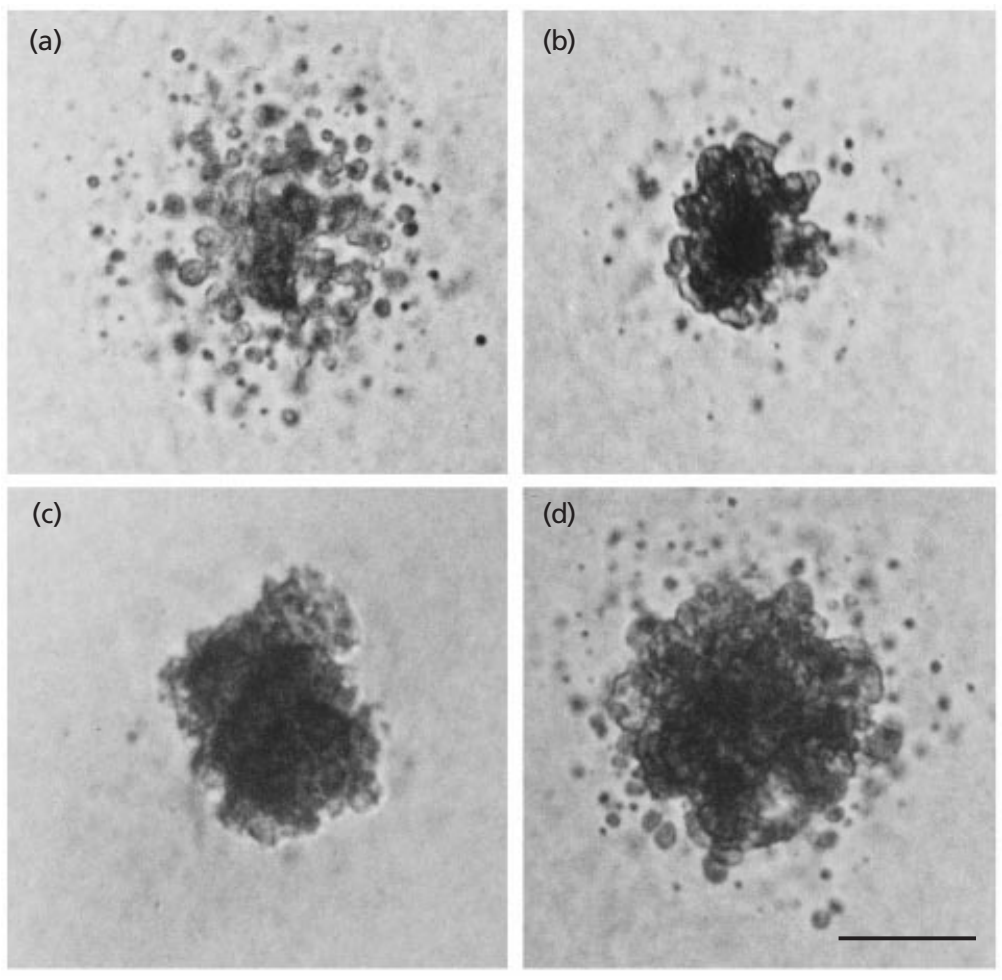

Fig. 1. Colony shapes of the wild-type strain (a) and mutants m6 (b), m12 (c) and m14 (d) in $0.1 \%$ agar medium. The colonies were photographed at $5 \mathrm{~d}$ old. Bar, $0.1 \mathrm{~mm}$. medium containing a low concentration of agar (Burchard, 1981; Hartzell \& Youderian, 1995). Мycoplasmas of the genus Spiroplasma have a helical cell morphology and show rotating motility in viscous environments, which generates a diffuse colony morphology in 0.6\% agar (Cohen et al., 1989; Jacob et al., 1997). These observations prompted us to test various agar concentrations of solid medium, i.e. $0 \cdot 1,0 \cdot 2,0 \cdot 3$, $0.5,0.7,1.0,1.5$ and $2.0 \%$, with the aim of finding one which would allow us to correlate the colony shape of M. mobile with the degree of gliding motility. In a medium containing more than $0.5 \%$ agar, M. mobile formed typical fried-egg colonies containing 'film and spots', which are caused by metabolic products (Freundt, 1983; Kirchhoff \& Rosengarten, 1984). At concentrations of less than $0.5 \%$ agar, colonies did not form a centre and a concentric peripheral zone, but were composed of irregular microcolonies (satellites), whilst the numbers and distribution of colonies in the inoculated area did not change. With decreasing concentrations of agar, the microcolonies increased in number and decreased in size. At concentrations of $0 \cdot 1 \%$ agar, most of the colonies were formed inside the medium and microcolonies predominated (Fig. 1a). In contrast, $M$. gallisepticum, which has a similar cell shape as $M$. mobile but glides at an extremely low speed of 0.03-0.05 $\mu \mathrm{m} \mathrm{s}{ }^{-1}$ (Kirchhoff, 1992; Morowitz \& Maniloff, 1966), formed colonies without satellites (data not shown). These results suggest that the colony morphology observed in less than $0.5 \%$ agar medium reflects the gliding ability of $M$. mobile. We adopted $0 \cdot 1 \%$ agar medium to try isolating gliding mutants because the difference in colony morphology between M. mobile and M. gallisepticum is most obvious at this agar concentration.

\section{Isolation of mutants}

Cells of the wild-type strain were irradiated by UV light to such an extent that the survival rate was about $10 \%$ and then inoculated onto $0.1 \%$ agar medium. In contrast to non-irradiated cell suspensions, about $0 \cdot 1 \%$ of the subsequent colonies showed abnormal shapes (Fig. 1). One morphotype (m12 in Fig. 1) was characterized by an opaque central area and lacking satellites (Fig. 1c). The other morphotype (m6 and $\mathrm{m} 14$ in Fig. 1) had a similar central area with surrounding satellites. Twenty mutants were isolated from about 20000 colonies screened by this method and the cells were checked by dark-field microscopy. Ten mutants exhibiting defects in gliding motility were isolated and designated $\mathrm{m} 6, \mathrm{~m} 9$, $\mathrm{m} 12, \mathrm{~m} 13, \mathrm{~m} 14, \mathrm{~m} 23, \mathrm{~m} 26, \mathrm{~m} 27, \mathrm{~m} 29$ and $\mathrm{m} 34$. No difference in growth rates was found among these mutants. We did not find any revertants during characterization of the isolated mutant strains, suggesting that they were genetically stable.

\section{Gliding motility of mutants}

Gliding of the wild-type cells and the mutant cells was examined by analysis of moving tracks produced from video tapes (Fig. 2). Features shown allowed classification of the mutants into four motility types. (i) 

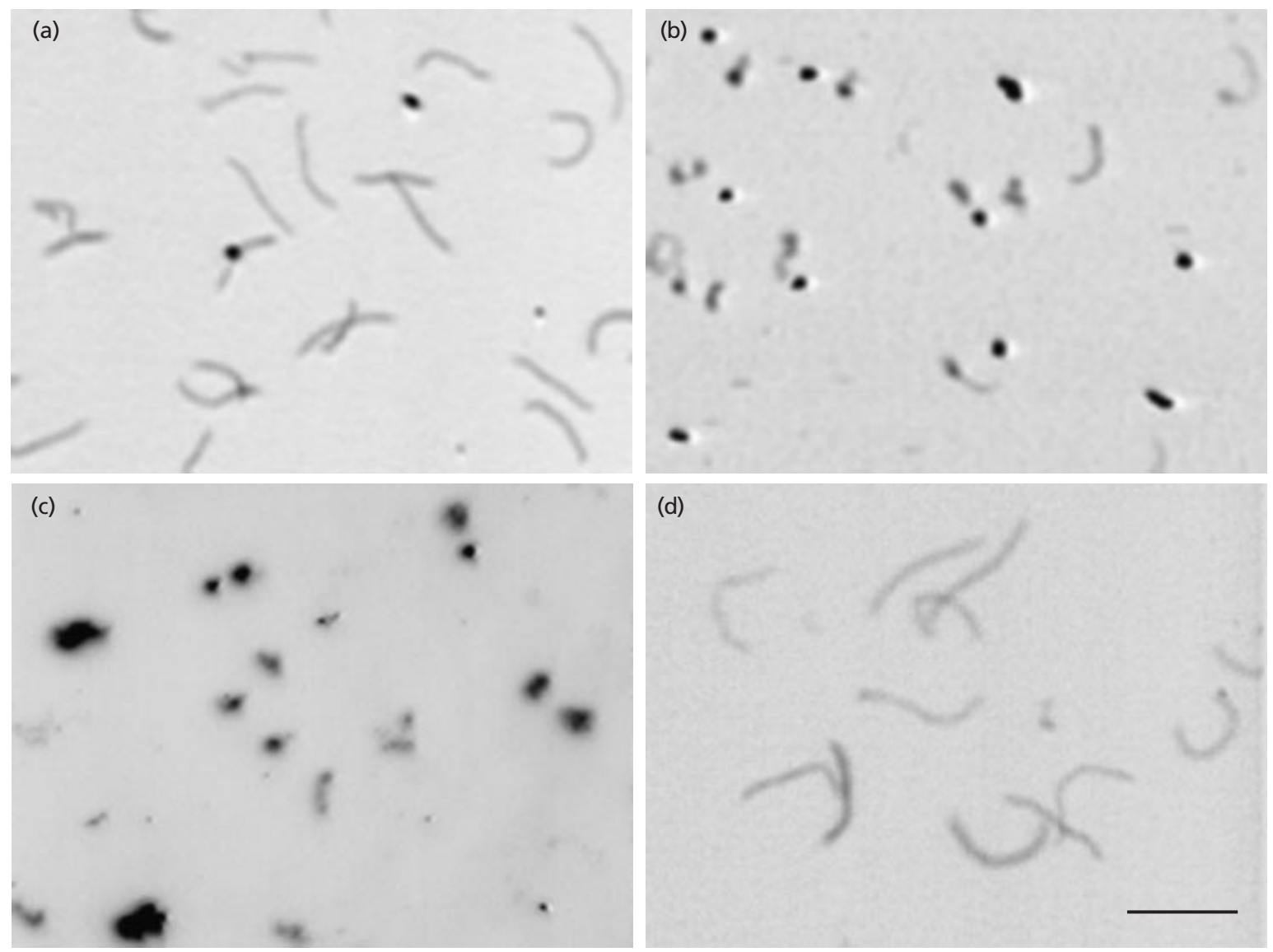

Fig. 2. Gliding tracks of the wild-type strain (a) and mutants $m 6$ (b), $m 12$ (c) and $m 14$ (d). Broth-grown mycoplasmas were transferred to glass slides and viewed by dark-field microscopy. The negative dark-field images of cell movements were obtained during exposure times of $4 \mathrm{~s}$. Bar, $10 \mu \mathrm{m}$.

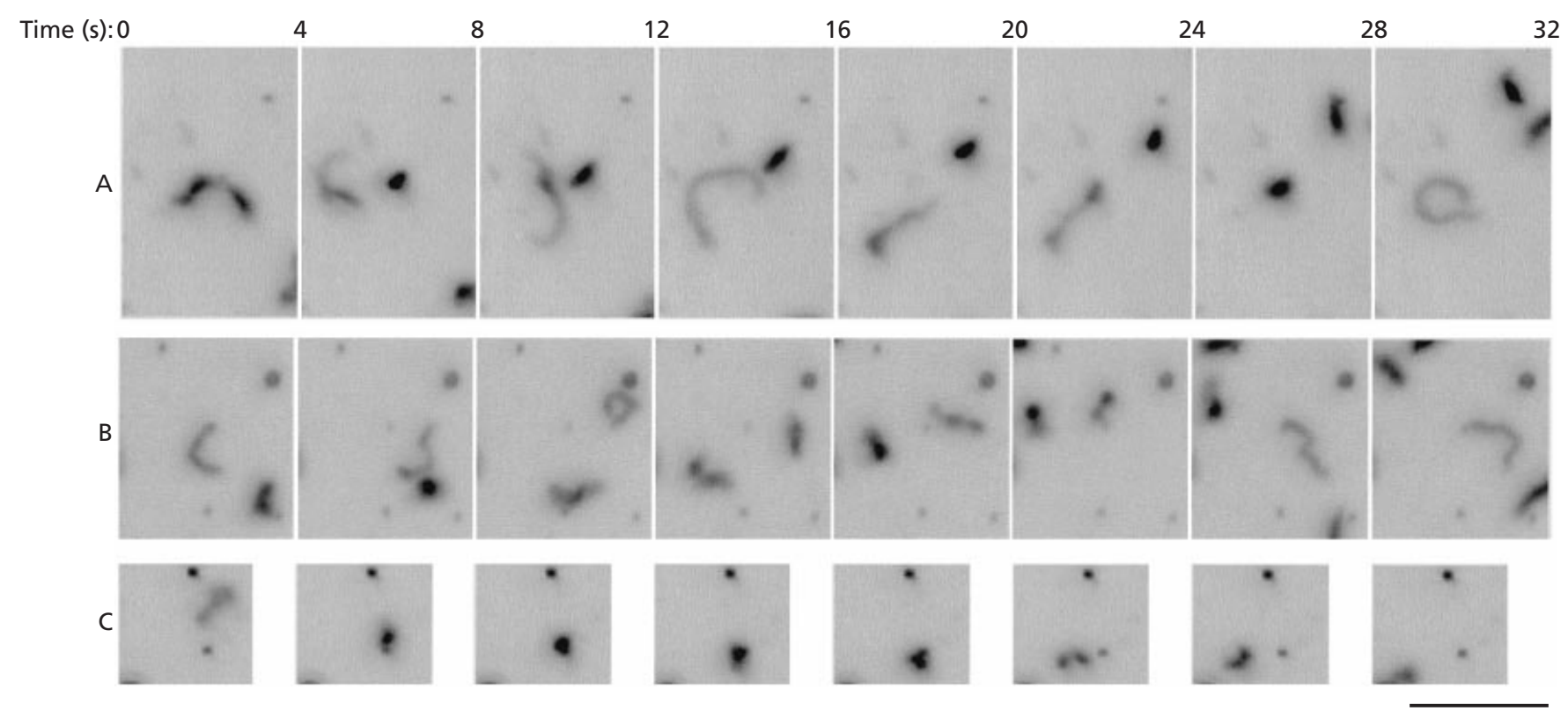

Fig. 3. Consecutive gliding tracks of $\mathrm{m} 6$. A series of eight still, negative dark-field video images obtained over $4 \mathrm{~s}$ are shown for three fields, designated A, B and C. The time at the start of each observation is shown at the top. Bar, $10 \mu \mathrm{m}$. 
Mutants $\mathrm{m} 9, \mathrm{~m} 12, \mathrm{~m} 13$ and $\mathrm{m} 23$ did not bind to the glass surface and exhibited only Brownian motion. (ii) Mutants m14, m27, m29 and m34 showed enhanced gliding speeds of $122,113,122$ and $123 \%$, respectively, compared to the gliding speed of $2.6 \mu \mathrm{m} \mathrm{s}^{-1}$ of the wildtype strain. (iii) Cells of mutant $\mathrm{m} 6$ had a reduced ability to bind to the glass surface and showed attachment and detachment with short intervals. More detailed observation of the movements of this mutant revealed three types (Fig. 3). The first was continuous gliding at $51 \%$ of the speed of the wild-type strain. The second type was slow movement with trembling and repeated attaching to and detaching from the glass surface over short intervals, resulting in thick and short tracks. The third type was Brownian movement, which generated a dot as the motility track. As seen in Fig. 3, the individual cells changed moving patterns frequently during the observation period, apparently because of their weak binding ability. The proportions of the three types of movements were estimated using eight consecutive still images of $2 \mathrm{~s}$ containing 155 tracks. The analysis revealed proportions of 23,31 and $46 \%$ for the first, second and third type of movement, respectively, whilst the proportions were 92,7 and $1 \%$, respectively, for the wild-type strain (based on 129 motility tracks). (iv) The majority of cells of mutant $\mathrm{m} 26$ did not bind to the glass surface and remained in Brownian motion, and only a small proportion bound to the glass surface. Less than $1 \%$ of the total cells showed occasional gliding at $18 \%$ of the speed of the wild-type.

\section{Cell morphology of mutants}

Cell morphology was analysed by dark-field (data not shown) and electron (Fig. 4) microscopy, and similar results were obtained by the two methods (Table 1). The wild-type cell was flask-shaped with a head-like structure, as previously reported (Kirchhoff \& Rosengarten, 1984). The cell shapes of the gliding mutants were classified into three types, which did not necessarily correspond to particular motility types. (i) Mutants m6 and $\mathrm{m} 34$ apparently showed the same cell morphology as the wild-type strain. (ii) Mutants $\mathrm{m} 9, \mathrm{~m} 12, \mathrm{~m} 13$ and $\mathrm{m} 23$ had an irregular cell morphology with a head-like structure that varied in length and was sometimes elongated. Observation by dark-field microscopy revealed that the elongated head-like structure was abnormally flexible and moved rapidly by Brownian motion (data not shown). The cells of these mutants easily formed aggregates in broth medium (Figs 2 and 4). The size of the cell bodies was less constant than that of the wild-type strain and sometimes swollen (Fig. 4). (iii) Cells of $\mathrm{m} 14, \mathrm{~m} 26, \mathrm{~m} 27$ and $\mathrm{m} 29$ showed a short flask shape. The length and width of individual cells was measured using dark-field microscopy images (Fig. 5). This revealed that the individual cells of $\mathrm{m} 14$ were shorter in length and wider than the wild-type strain. The same feature was found in analyses of $\mathrm{m} 26, \mathrm{~m} 27$ and $\mathrm{m} 29$ (data not shown). The mean lengths of the long axis were $81,90,78$ and $81 \%$ of that of wild-type cells

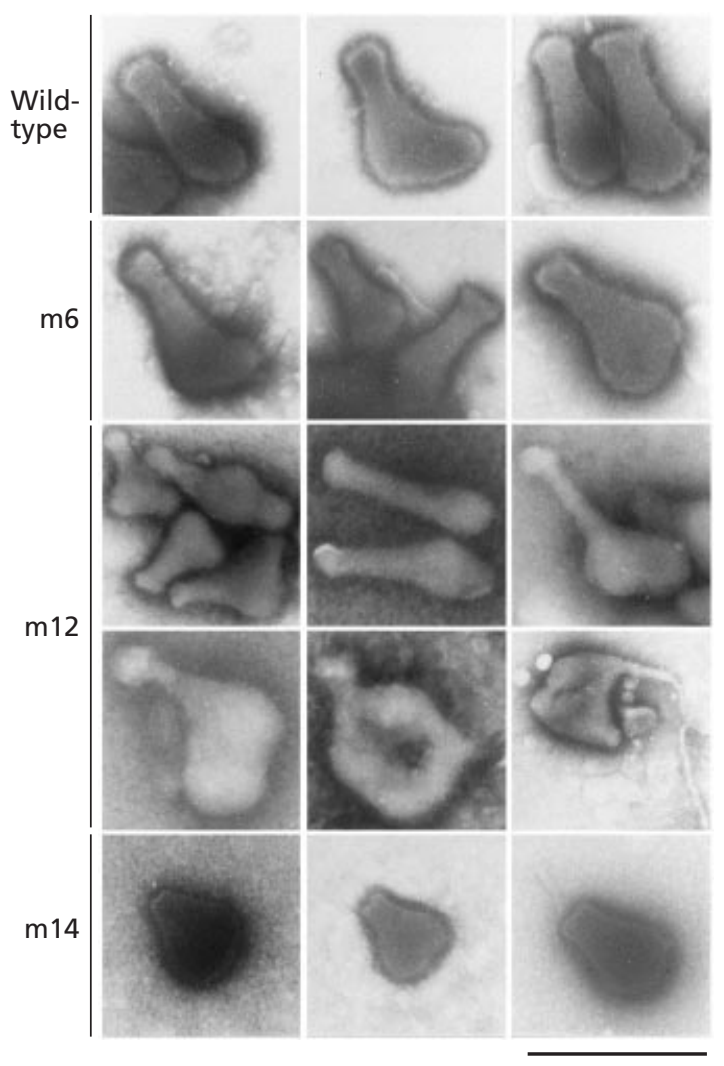

Fig. 4. Electron micrographs of negatively stained cells of the wild-type strain and mutants $\mathrm{m} 6, \mathrm{~m} 12$ and $\mathrm{m} 14$. Bar, $1 \mu \mathrm{m}$.

for $\mathrm{m} 14, \mathrm{~m} 26, \mathrm{~m} 27$ and $\mathrm{m} 29$, respectively, whilst the mean widths were $121,123,118$ and $118 \%$, respectively.

\section{Classification of mutants}

Based on their cell morphology, their attachment capability and their gliding motility, the mutants were classified into two groups. Mutants $\mathrm{m} 9, \mathrm{~m} 12, \mathrm{~m} 13$ and $\mathrm{m} 23$, which had irregular cell shapes and no binding activity to glass surfaces were classified as group I mutants. Mutants $\mathrm{m} 14, \mathrm{~m} 27$ and $\mathrm{m} 29$, which had short flask shapes and fast gliding speeds were classified as group II mutants. The other three mutants $(\mathrm{m} 6, \mathrm{~m} 26$ and m34) could not be classified using these criteria.

\section{Haemadsorption activity}

It has been previously shown that the haemadsorption activity is related to so-called cytadherence-associated proteins (Krause et al., 1997). However, it is unknown whether the binding activity required for gliding depends on these components (Bredt, 1979; Kirchhoff, 1992). To evaluate such a possible relationship, the ability of colonies to adsorb erythrocytes was examined for the ten mutants and the wild-type strain (Fig. 6). Colonies 
Table 1. Summary of mutant characteristics

\begin{tabular}{|c|c|c|c|c|c|c|c|c|}
\hline Group & Strain & $\begin{array}{c}\text { Relative } \\
\text { gliding } \\
\text { speed } \\
(\%)^{*}\end{array}$ & Cell shape & $\begin{array}{l}\text { Long axis } \\
\qquad(\mu \mathrm{m}) \dagger\end{array}$ & $\begin{array}{l}\text { Short axis } \\
\qquad(\mu \mathrm{m}) \dagger\end{array}$ & $\begin{array}{l}\text { Cells bound } \\
\text { to glass } \\
\text { surface } \\
(\%) \neq\end{array}$ & $\begin{array}{c}\text { Haemadsorption } \\
\text { activity }(\%) \mathbb{S}\end{array}$ & $\begin{array}{l}\text { Microcolony } \\
\text { formation }\end{array}$ \\
\hline & Wild-type & 100 & Flask & $1 \cdot 04(0.15)$ & $0.56(0.07)$ & 99 & 100 & + \\
\hline I & $\begin{array}{l}\mathrm{m} 9, \mathrm{~m} 12, \\
\mathrm{~m} 13, \mathrm{~m} 23\end{array}$ & 0 & $\begin{array}{l}\text { Irregular (elongated } \\
\text { and flexible head of } \\
\text { different length, } \\
\text { swollen body) }\end{array}$ & ND & ND & - & 0 & - \\
\hline \multirow[t]{3}{*}{ II } & $\mathrm{m} 14$ & $122(20)$ & Short flask & $0 \cdot 84(0 \cdot 12)$ & $0.68(0.09)$ & + & 93 & + \\
\hline & $\mathrm{m} 27$ & $113(17)$ & Short flask & $0 \cdot 81(0 \cdot 11)$ & $0 \cdot 66(0 \cdot 08)$ & + & 113 & + \\
\hline & $\mathrm{m} 29$ & $122(21)$ & Short flask & $0 \cdot 84(0 \cdot 14)$ & $0.66(0.09)$ & + & 96 & + \\
\hline- & $\mathrm{m} 6$ & $51(13)$ & Flask & $\mathrm{ND}$ & $\mathrm{ND}$ & 54 & 24 & $(+) \|$ \\
\hline- & $\mathrm{m} 26$ & {$[18(6)] \mathbf{9}$} & Short flask & $0 \cdot 94(0 \cdot 14)$ & $0.69(0.11)$ & - & 0 & - \\
\hline- & $\mathrm{m} 34$ & $123(25)$ & Flask & $\mathrm{ND}$ & ND & + & 122 & + \\
\hline
\end{tabular}

*Values $( \pm \mathrm{SD})$ are based on the mean speed of $2 \cdot 6 \mu \mathrm{m} \mathrm{s}^{-1}$ of the wild-type strain.

$\dagger$ Values are means $( \pm \mathrm{SD})$. ND, Not determined.

$\ddagger$ Numbers of bound cells were estimated from 155 tracks in still images obtained with exposure times of $2 \mathrm{~s}$. Values represent the proportion of cells showing continuous gliding and slow movements with trembling. + , Binding similar to that of wild-type; - , no binding.

\Calculated as number of adsorbed erythrocytes per colony area in relation to the mean value of 380 erythrocytes per $100 \mu \mathrm{m}^{2}$ obtained for the wild-type strain. Values are means obtained for four colonies.

\| Microcolonies were less dense.

I Less than $1 \%$ of total cells showed occasional gliding.

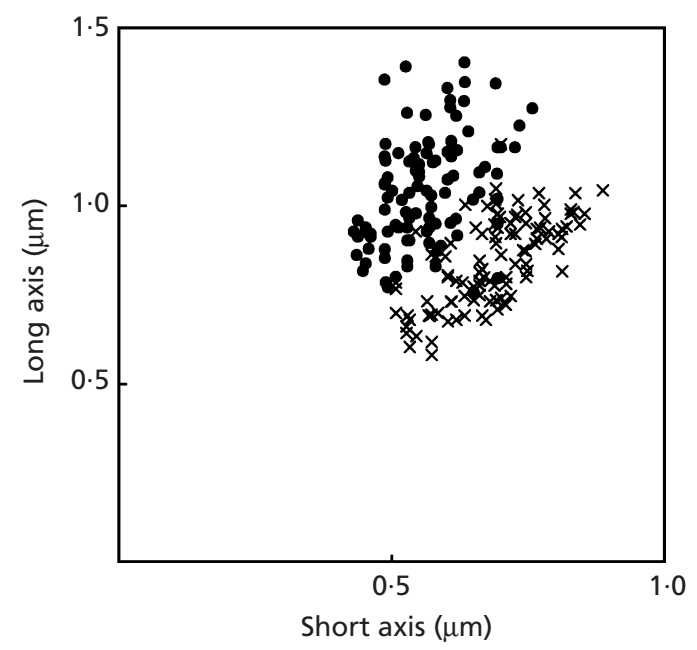

Fig. 5. Axis lengths of individual cells of the wild-type strain (circles) and mutant m14 (crosses).

on $0.7 \%$ agar plates were overlaid with erythrocytes suspended in PBS. Haemadsorption activity was quantified from the number of erythrocytes adsorbed to the colony surface and the colony area (Table 1). The colonies of $\mathrm{m} 14, \mathrm{~m} 27, \mathrm{~m} 29$ and $\mathrm{m} 34$ had haem- adsorption activities of 93, 113, 96 and $122 \%$ of that of the wild-type strain, respectively. The colonies of $\mathrm{m} 9, \mathrm{~m} 12, \mathrm{~m} 13, \mathrm{~m} 23$ and $\mathrm{m} 26$ failed to adsorb erythrocytes. The colonies of $\mathrm{m} 6$ had $24 \%$ of the haemadsorption activity of the wild-type strain. These results showed that haemadsorption activity correlates with the binding activity required for gliding motility.

\section{Microcolony formation}

The wild-type strain and the mutants were examined for their ability to form microcolonies on a solid surface in broth medium (Fig. 7). Microcolonies emerged on the bottom of the microtitre plate wells about $30 \mathrm{~h}$ after inoculation and grew with small changes in their position, presumably caused by the gliding motility of individual cells (data not shown). The slow colony movement was observed until $50 \mathrm{~h}$ after inoculation. The mutants were grown and observed in the same way. No microcolony formation was found in cultures of group I and $\mathrm{m} 26$ mutants, whilst the group II and $\mathrm{m} 34$ mutants formed microcolonies in a similar manner to the wild-type strain. In cultures of the m6 mutant, microcolonies were formed, but they were less condensed than those seen in the wild-type strain. These results indicated that microcolony formation correlates with the ability to glide. 

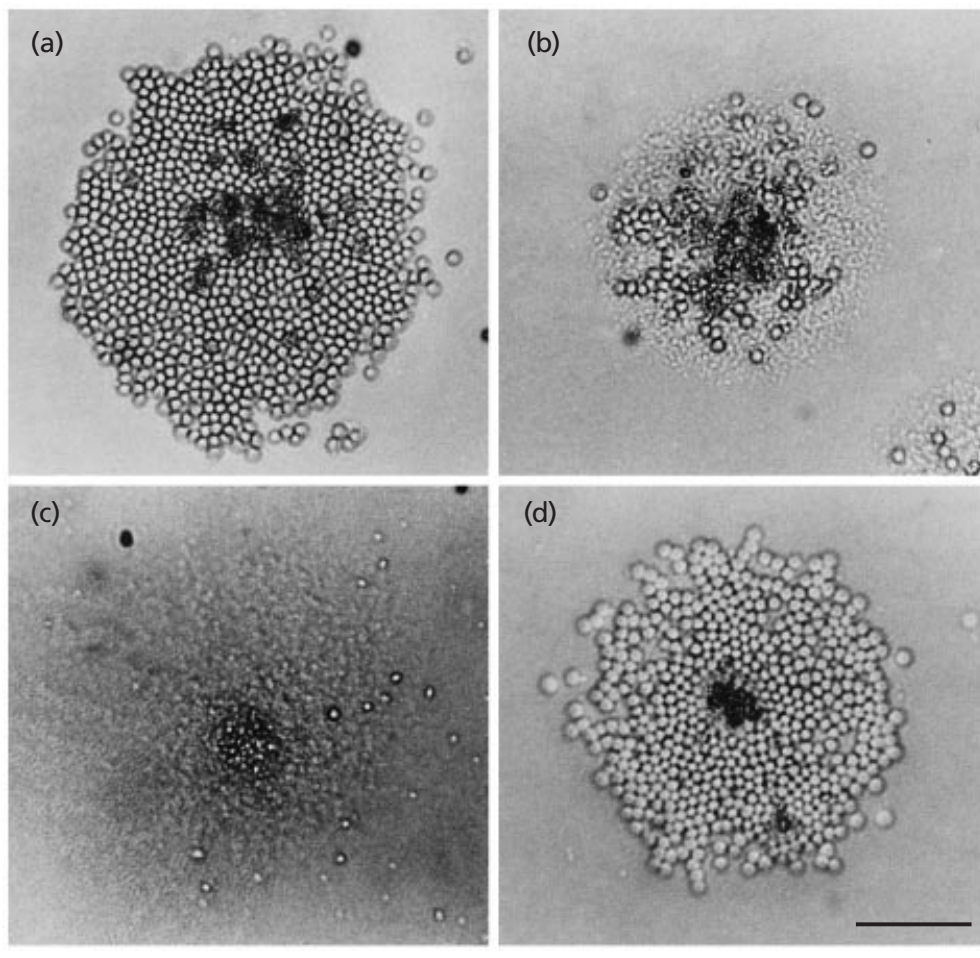

Fig. 6. Haemadsorption activity of the wildtype strain (a) and mutants $\mathrm{m} 6$ (b), $\mathrm{m} 12$ (c) and $\mathrm{m} 14$ (d). Five-day-old colonies on $0.7 \%$ agar medium were overlaid with sheep erythrocytes and washed with PBS. The central dark zone of the typical fried-egg shaped colonies show less haemadsorption activity. Bar, $50 \mu \mathrm{m}$.
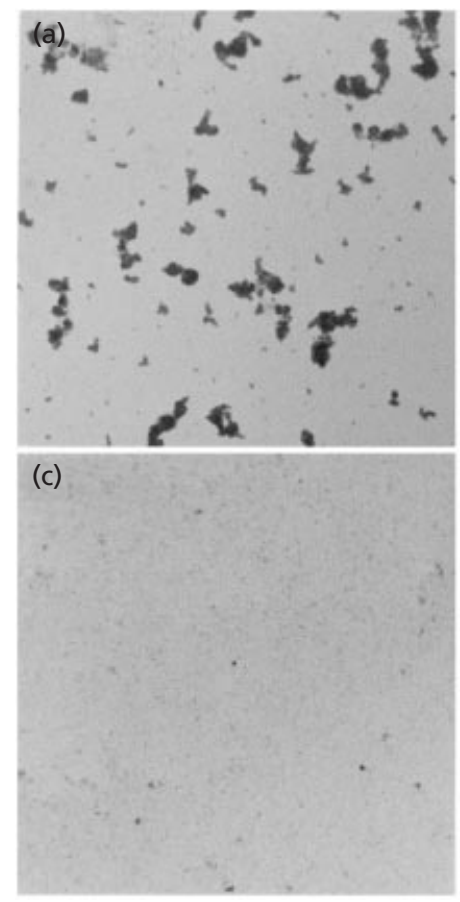
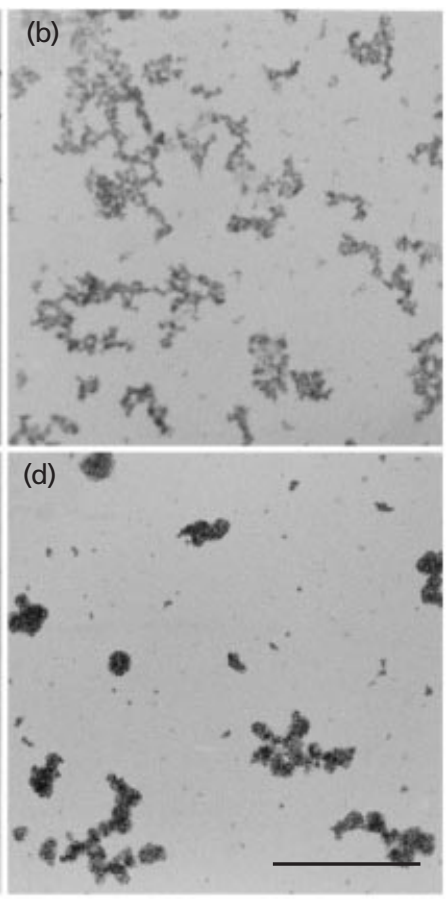

Fig. 7. Microcolony formation of the wildtype strain (a) and mutants $\mathrm{m} 6$ (b), $\mathrm{m} 12$ (c) and $\mathrm{m}_{14}$ (d). The cells (inoculum size $1 \times 10^{7}$ c.f.u. $\mathrm{ml}^{-1}$ ) were grown in 96-well microtitre plates at $25^{\circ} \mathrm{C}$ for $60 \mathrm{~h}$ and photographed with an inverted microscope. Bar, $0.5 \mathrm{~mm}$.

\section{DISCUSSION}

In the present study the colony morphology of the wildtype strain and UV-induced mutants of M. mobile was examined in medium with low agar concentrations. While the wild-type strain showed a distinct colony shape composed of microcolonies, immobile group I and m26 mutants formed dense colonies without satellites, and the m6 mutant displaying reduced cell motility formed colonies with an intermediate shape (Fig. 1). These observations suggest that in low agar concentrations colony morphology correlates with the gliding activity of the mutant strains. Since colonies on media with agar concentrations higher than $0.5 \%$ and containing agar other than Noble agar from Difco did not show the same shape, it seems that the colony 
morphology of M. mobile depends on the structure of the agar network.

Colony morphology changed continuously depending on the agar concentration but the number and distribution of the colonies remained constant. When a series of diluted cells was inoculated onto the soft agar, colonies composed of small blocks of cells were not obtained until they had grown for a few days (data not shown). These observations suggest that colonies in $0.1 \%$ agar are a variation of the usual ones resulting from proliferation of a single cell, and are not formed by cell aggregation. It is likely that M. mobile cells glide on the agar fibres through the network and then stop occasionally and form microcolonies. In the higher concentrations of agar, movement is presumably inhibited by the fine agar network. When the same agar medium was used for $M$. gallisepticum, which glides with a slow speed (Kirchhoff, 1992; Morowitz \& Maniloff, 1966) the resulting colonies were similar to those of the immobile mutants of M. mobile. However, colony shape seems not to depend on motility alone. Colonies of group II and m34 mutants had greatly reduced numbers of satellites although the cells had similar motility to the wild-type strain. (Figs 1 and 2). Moreover, some M. mobile mutants had normal cell shapes and motility, but their colony shapes were similar to the immobile mutants (data not shown). Chemotactic behaviour towards some sugars and amino acids has been reported for M. mobile and M. pneumoniae (Kirchhoff, 1992; Kirchhoff et al., 1987b), although no homologues of chemotaxis genes were found in the deduced genome sequences of $M$. pneumoniae and $M$. genitalium (Fraser et al., 1995; Himmelreich et al., 1996). It is not unlikely that chemotactic activity may act as one triggering factor for colony morphology in $M$. mobile. The change in colony morphology depending on both agar concentration and motility is also observed in spiroplasmas, one genus of the mycoplasmas (Jacob et al., 1997). However, their motility is apparently different from gliding, namely rotatory and flexible movements in liquid of high viscosity. This observation is supported by the finding that the essential gene for spiroplasma motility has no homologues in the genomes of two gliding mycoplasmas.

A total of ten mutants were isolated, of which seven were classified into two groups, as summarized in Table 1. The cells of group I mutants lacked binding activity to the glass surface ( $\mathrm{m} 12$ in Fig. 2$)$ and had a head-like structure of variable length and abnormal flexibility in the elongated forms (m12 in Fig. 4). It was previously reported that M. mobile cells appear to bind to glass surfaces with their head-like structure because they were sometimes seen to tremble, thereby keeping their headlike structure attached to the glass surface (Kirchhoff, 1992). Presumably, a non-functional head-like structure causes the loss of binding and gliding activity in the group I mutants. In M. pneumoniae, the head-like structure is designated as the attachment organelle and functions in adhesion to host cells and other solid matrices (Krause, 1996, 1998). Several proteins of $M$. pneumoniae, including HMW1, HMW3, P1, P30, P40, $\mathrm{P} 90$ and P65, which are located at the attachment organelle are known to be essential for cytadherence $(S$. Seto, G. Layh-Schmitt, T. Kenri \& M. Miyata, unpublished). The HMW1 protein plays a role in an early stage of organelle formation and hmw1 defective mutants of M. pneumoniae do not express the typical tapered morphology of the attachment organelle (Hahn et al., 1998). The deficiencies of group I mutants of $M$. mobile may be caused by a similar mechanism to that of the bmw1 mutants of M. pneumoniae.

In the head-like structure of some gliding mycoplasmas, cytoskeleton-like filaments have been identified (Korolev et al., 1994; Meng \& Pfister, 1980). In M. pneumoniae, actin-like filaments bind to the pole of the head-like structure and form a network in the cell body. Korolev et al. (1994) found that in M. gallisepticum a submembrane system is formed of tubules similar to eukaryotic microtubules and both ends of the tubular structures are anchored in the head-like structure of the cell (Korolev et al., 1994). No filamentous structures were reported for M. mobile (Kirchhoff et al., 1987a; Kirchhoff \& Rosengarten, 1984). However, the present observation of abnormal flexibility in the elongated heads of group I mutants suggests the participation of cytoskeleton-like structures in organizing the apparatus responsible for gliding motility.

The gliding speed of individual cells of the wild-type strain ranged from 2.4 to $3.3 \mu \mathrm{m} \mathrm{s}^{-1}$ and was dependent on the batch of serum added to the medium, suggesting that unknown factors in the serum influence gliding motility. However, the ratio of the speed of the mutants to that of the wild-type strain did not change significantly among the measurements. One interesting finding was that group II mutants, $\mathrm{m} 14, \mathrm{~m} 27$ and $\mathrm{m} 29$, had a rather round cell shape that correlated with enhanced gliding speeds (m14 in Figs 2, 4 and 5). The procedure for isolating mutants did not include a growth step until the first inoculation on the ultrasoft agar followed by colony selection. Moreover, we isolated the mutants from two separate cell suspensions mutated independently. These facts suggest that the three mutants were produced independently, and that the rounded cell shape is intrinsically related to the increased gliding speed. On the other hand, the round cell shape is probably not the result of the enhanced gliding motility because $\mathrm{m} 34$ cells showed an enhanced motility but a normal (wild-type) cell morphology.

In $M$. pneumoniae, the P1 adhesin supported by accessory proteins is known to bind to solid surfaces and animal cells (Krause, 1996, 1998). The adhesion mechanism of M. gallisepticum seems to be similarly complex (Athamna et al., 1997). However, it is as yet unclear whether the apparatus for adhesion to animal cells also mediates the binding to the glass surface required for gliding motility (Kirchhoff, 1992). In cyanobacteria, it is suggested that constantly secreted slime plays key roles in both adherence to the substrate surface and production of the motive force (Hoiczyk \& Baumeister, 1998). In M. mobile, slime has been observed to 
surround the cells (Rosengarten et al., 1988). To elucidate the relationship between cell adhesion and gliding, the cell adhesion activity of the mutants and the wild-type strain was examined in the haemadsorption assay (Fig. 6). The group II and m34 mutants, which were shown to glide with similar speed as the wild-type strain, also had a wild-type-like haemadsorption activity, whilst immobile group I and m26 mutants, which did not bind to the glass surface, had no haemadsorption activity. Interestingly, mutant $\mathrm{m} 6$, in which the proportion of cells that bound to the glass surface was half of that of the wild-type strain, had an intermediate haemadsorption activity. These results showed that haemadsorption activity correlates to the binding activity required for gliding, suggesting that the machinery for cell adhesion is also used for gliding motility.

Surface motility of Myxococcus xanthus and Pseudomonas aeruginosa is known to be involved in microcolonization prior to the development of microbial communities (Hartzell \& Youderian, 1995; O’Toole \& Kolter, 1998). Although microcolonization has been previously reported for M. mobile, the involvement of gliding motility has not been defined (Rosengarten \& Kirchhoff, 1989). The present results indicate that gliding motility plays a critical role in microcolony formation, suggesting that gliding mycoplasmas may use their motility not only for migration to the preferred locations in the host, but also for successful colonization of host tissues.

The microscopic observations revealed that cells of mutant $\mathrm{m} 6$ repeatedly attached to and detached from the glass surface, and that the gliding speed during the binding period reached only $50 \%$ of that of the wildtype cells (Figs 2 and 3). All mutants with reduced or no gliding activity had an additional deficiency in adhesion to the glass surface. The relationship between gliding and attachment was examined in further experiments by applying poly-L-lysine coated glass slides to bind the non-adhesive mutants of M. mobile. Most of the mutant cells became bound to the glass but they did not glide, whilst the gliding speed of the wild-type cells was not significantly affected (data not shown). These observations suggest that an active natural binding of cells to a solid surface is required for gliding motility, and that binding and gliding activities are linked to each other. Another possible explanation for the failure to isolate mutants deficient only in motility is that the motility is linked to a cellular event essential for growth, for example membrane potential, basic metabolism or synthesis of macromolecules.

Six of the isolated mutants showed striking differences in binding activity to both glass and erythrocytes compared to the wild-type strain, suggesting changes in cell surface structures. In Gram-negative bacteria, lipopolysaccharide (LPS) plays an important role in adhesion to solid and host surfaces (Jacques, 1996). Similar molecules called lipoglycan have been reported for a limited number of mycoplasma species (Smith \& Langworthy, 1983). Since lipoglycan was not identified in M. mobile (data not shown), the profile of membrane proteins was analysed by Triton X-114 phase fractionation and SDS-PAGE (data not shown). Some differences were found in the protein profiles between the mutants and the wild-type strain, but these were limited to the intensity of bands and did not reveal defined ON or OFF expression states, as reported for phase variation in many mycoplasma species (Citti \& Rosengarten, 1997). Therefore, it appears difficult to link changes in gliding motility with changes in the protein profile.

Some cytadherence-associated proteins of M. pneumoniae have been identified by exploring the protein profiles of the cytoskeleton, which is insoluble in Triton X-100 and designated the 'Triton shell' (Krause, 1996). The successful identification of mutated proteins by comparing protein profiles depends on the genome size. The genome sizes of M. mobile, M. genitalium and M. pneumoniae are 780, 580 and $816 \mathrm{~kb}$, respectively (Bautsch, 1988; Fraser et al., 1995; Himmelreich et al., 1996). We anticipate for M. mobile a potential ORF number of 600-650, based on the putative ORF numbers of M. pneumoniae and M. genitalium. This expected number is much smaller than the 4288 ORFs of Escherichia coli (Blattner et al., 1997) and will be advantageous for the direct identification of proteins involved in gliding motility and associated functions.

\section{ACKNOWLEDGEMENTS}

We are grateful to Karin Siebert-Gulle for excellent technical assistance. This study was supported in part by internal funds of the Institute of Bacteriology, Mycology and Hygiene at the University of Veterinary Medicine, Vienna, Austria, and by a grant-in-aid for Encouragement of Young Scientists from the Ministry of Education, Science and Culture of Japan.

\section{REFERENCES}

Aluotto, B. B., Wittler, R. G., Williams, C. O. \& Faber, J. E. (1970). Standardized bacteriologic techniques for the characterization of mycoplasma species. Int J Syst Bacteriol 20, 35-58.

Athamna, A., Rosengarten, R., Levisohn, S., Kahane, I. \& Yogev, D. (1997). Adherence of Mycoplasma gallisepticum involves variable surface membrane proteins. Infect Immun 65, 2468-2471.

Bautsch, W. (1988). Rapid physical mapping of the Mycoplasma mobile genome by two-dimensional field inversion gel electrophoresis techniques. Nucleic Acids Res 16, 11461-11467.

Blattner, F. R., Plunkett, G., III, Bloch, C. A. \& 14 other authors (1997). The complete genome sequence of Escherichia coli K-12. Science 277, 1453-1474.

Bredt, W. (1979). Motility. In The Mycoplasmas, pp. 141-145. Edited by M. F. Barile, S. Razin, J. G. Tully \& R. F. Whitcomb. New York: Academic Press.

Burchard, R. B. (1981). Gliding motility of prokaryotes: ultrastructure, physiology, and genetics. Annu Rev Microbiol 35, 497-529.

Citti, C. \& Rosengarten, R. (1997). Mycoplasma genetic variation and its implication for pathogenesis. Wien Klin Wochenschr 109, 562-568.

Cohen, A. J., Williamson, D. L. \& Brink, P. R. (1989). A motility mutant of Spiroplasma melliferium induced with nitrous acid. Curr Microbiol 18, 219-222. 
Cole, R. M. (1983). Transmission electron microscopy: basic techniques. Methods Mycoplasmol 1, 43-50.

Fareed, G. C. \& Kasamatsu, H. (1980). Electron microscopic methods for localizing the origin and termination points for DNA replication. In Nucleic Acids Part I, pp. 709-717. Edited by L. Grossman \& K. Moldave. New York: Academic Press.

Fraser, C. M., Gocayne, J. D., White, O. \& 26 other authors (1995). The minimal gene complement of Mycoplasma genitalium. Science 270, 397-403.

Freundt, E. A. (1983). Film and spot production. Methods Mycoplasmol 1, 373-374.

Hahn, T. W., Willby, M. J. \& Krause, D. C. (1998). HMW1 is required for cytadhesin $\mathrm{P} 1$ trafficking to the attachment organelle in Mycoplasma pneumoniae. J Bacteriol 180, 1270-1276.

Hartzell, P. L. \& Youderian, P. (1995). Genetics of gliding motility and development in Myxococcus xanthus. Arch Microbiol 164, 309-323.

Himmelreich, R., Hilbert, H., Plagens, H., Pirkl, E., Li, B.-C. \& Herrmann, R. (1996). Complete sequence analysis of the genome of the bacterium Mycoplasma pneumoniae. Nucleic Acids Res 24, 4420-4449.

Hoiczyk, E. \& Baumeister, W. (1998). The junctional pore complex, a prokaryotic secretion organelle, is the molecular motor underlying gliding motility in cyanobacteria. Curr Biol 8, 1161-1168.

Jacob, C., Nouzieres, F., Duret, S., Bove, J. M. \& Renaudin, J. (1997). Isolation, characterization, and complementation of a motility mutant of Spiroplasma citri. J Bacteriol 179, 4802-4810.

Jacques, M. (1996). Role of lipo-oligosaccharides and lipopolysaccharides in bacterial adherence. Trends Microbiol 4, 408-409.

Kirchhoff, H. (1992). Motility. In Mycoplasmas-Molecular Biology and Pathogenesis, pp. 289-306. Edited by J. Maniloff, R. N. McElhaney, L. R. Finch \& J. B. Baseman. Washington, DC: American Society for Microbiology.

Kirchhoff, H. \& Rosengarten, R. (1984). Isolation of a motile mycoplasma from fish. J Gen Microbiol 130, 2439-2445.

Kirchhoff, H., Beyene, P., Fischer, M. \& 7 other authors (1987a). Mycoplasma mobile sp. nov., a new species from fish. Int J Syst Bacteriol 37, 192-197.

Kirchhoff, H., Boldt, U., Rosengarten, R. \& Klein-Struckmeier, A. (1987b). Chemotactic response of a gliding mycoplasma. Curr Microbiol 15, 57-60.

Korolev, E. V., Nikonov, A. V., Brudnaya, M. S., Snigirevskaya, E. S., Sabinin, G. V., Komissarchik, Y. Y., Ivanov, P. I. \& Borchsenius, S. N. (1994). Tubular structures of Mycoplasma gallisepticum and their possible participation in cell motility. Microbiology 140, 671-681.

Krause, D. C. (1996). Mycoplasma pneumoniae cytadherence: unravelling the tie that binds. Mol Microbiol 20, 247-253.

Krause, D. C. (1998). Mycoplasma pneumoniae cytadherence: organization and assembly of the attachment organelle. Trends Microbiol 6, 15-18.
Krause, D. C., Proft, T., Hedreyda, C. T., Hilbert, H., Plagens, H. \& Herrmann, R. (1997). Transposon mutagenesis reinforces the correlation between Mycoplasma pneumoniae cytoskeletal protein HMW2 and cytadherence. J Bacteriol 179, 2668-2677.

Manson, M. D., Armitage, J. P., Hoch, J. A. \& Macnab, R. M. (1998). Bacterial locomotion and signal transduction. J Bacteriol 180, 1009-1022.

Meng, K. E. \& Pfister, R. M. (1980). Intracellular structures of Mycoplasma pneumoniae revealed after membrane removal. $J$ Bacteriol 144, 390-399.

Miyata, M. \& Seto, S. (1999). Cell reproduction cycle of mycoplasma. Biochimie 81, 873-878.

Morowitz, H. J. \& Maniloff, J. (1966). Analysis of the life cycle of Mycoplasma gallisepticum. J Bacteriol 91, 1638-1644.

O'Toole, G. A. \& Kolter, R. (1998). Flagellar and twitching motility are necessary for Pseudomonas aeruginosa biofilm development. Mol Microbiol 30, 295-304.

Razin, S. (1995). Molecular properties of mollicutes : a synopsis. In Molecular and Diagnostic Procedures in Mycoplasmology, pp. 1-25. Edited by S. Razin \& J. G. Tully. Tokyo: Academic Press.

Rosengarten, R. \& Kirchhoff, H. (1987). Gliding motility of Mycoplasma sp. nov. strain 163K. J Bacteriol 169, 1891-1898.

Rosengarten, R. \& Kirchhoff, H. (1989). Growth morphology of Mycoplasma mobile $163 \mathrm{~K}$ on solid surfaces: reproduction, aggregation, and microcolony formation. Curr Microbiol 18, 15-22.

Rosengarten, R., Kirchhoff, H., Kerlen, G. \& Seack, K.-H. (1988). The surface layer of Mycoplasma mobile $163 \mathrm{~K}$ and its possible relevance to cell cohesion and group motility. J Gen Microbiol 134, 275-281.

Seto, S. \& Miyata, M. (1998). Cell reproduction and morphological changes in Mycoplasma capricolum. J Bacteriol 180, 256-264.

Seto, S. \& Miyata, M. (1999). Partitioning, movement, and positioning of nucleoids in Mycoplasma capricolum. J Bacteriol 181, 6073-6080.

Smith, P. F. \& Langworthy, T. A. (1983). Characterization of membrane lipoglycans. In Methods Mycoplasmol 1 277-283.

Sobeslavsky, O., Prescott, B. \& Chanock, R. M. (1968). Adsorption of Mycoplasma pneumoniae to neuraminic acid receptors of various cells and possible role in virulence. J Bacteriol 96, $695-705$.

Wall, D. \& Kaiser, D. (1999). Type IV pili and cell motility. Mol Microbiol 32, 1-10.

Weisburg, W. G., Tully, J. G., Rose, D. L. \& 9 other authors (1989). A phylogenetic analysis of the mycoplasmas: basis for their classification. J Bacteriol 171, 6455-6467.

Youderian, P. (1998). Bacterial motility: secretory secrets of gliding bacteria. Curr Biol 8, R408-R411.

Received 28 October 1999; revised 28 February 2000; accepted 7 March 2000. 